\title{
Powder Characteristics on the Rheological Performance of Resin-based Zirconia Suspension for Stereolithography
}

\author{
LI Xing-Bang ${ }^{1,2}$, ZHONG He $^{1}$, ZHANG Jing-Xian ${ }^{1,3}$, DUAN Yu-Sen ${ }^{1,2}$, JIANG Dong-Liang ${ }^{1}$
}

(1. State Key Laboratory of High Performance Ceramics and Superfine Microstructure, Shanghai Institute of Ceramics, Chinese Academy of Sciences, Shanghai 200050, China; 2. University of Chinese Academy of Sciences, Beijing 100049, China; 3. Suzhou Institute of SICCAS (Shanghai Institute of Ceramics, Chinese Academy of Sciences), Taicang 215499, China)

\begin{abstract}
As for ceramic stereolithography technique, the preparation of suitable resin-based ceramic slurry is of primary importance. In this study, the effects of powder characteristics such as specific surface area, particle size and distribution, particle morphology on the rheological behavior of zirconia resin-based suspensions were investigated intensively. Results show that the specific surface area of the powder is the most important factor affecting slurry viscosity. Choosing low specific surface area and quasi-spherical shaped powder is more likely to obtain low viscosity slurries. In addition, the influence of solid loading on the flow behavior were also studied using Krieger-Dougherty model. Zirconia samples with the relative density of $(97.83 \pm 0.33) \%$ were obtained after sintering at $1550{ }^{\circ} \mathrm{C}$. No obvious abnormal grain growth in the microstructure of the sintered body is observed. Results indicate that after the optimization of the processing parameters with the help of rheology characterization, complex-shaped high-quality zirconia parts can be obtained using the stereolithography technique.
\end{abstract}

Key words: zirconia; ceramic stereolithography; slurry; rheological properties

Ceramic parts are difficult to be shaped and processed due to their extreme hardness and brittleness. Although the conventional colloidal processing is an ideal way to achieve homogeneous microstructure for the green bodies, the post machining causes high cost in time and money and thus limits its applications. As one of the additive manufacturing techniques, ceramic stereolithography has drawn much attention because it can be used to fabricate high-precision complex-shaped ceramic green components without using mold, as compared with traditional ceramic shaping and processing method. To date, researchers have applied ceramic stereolithography to make piezoceramic transducer array ${ }^{[1-2]}$, cutting tool ${ }^{[3]}$, integrally cored ceramic mold ${ }^{[4]}$, YSZ electrolyte ${ }^{[5-6]}$, and so on.

To obtain dense ceramic parts with less defects, preparation of suspension with high solid loading, low viscosity is essential. In general, most of the current ceramic stereolithography suspensions can be divided into two groups: aqueous acrylamide-based system and non-aqueous resin-based system, depending on the matrix solutions used for preparing the slurries ${ }^{[7]}$. For the acrylamide-based system, acrylamide (AM) and $N, N$ '-methylenebisacrylamide (MBAM) usually act as organic monomer and cross-linker, respectively, similar to ordinary gelcasting ${ }^{[3,8-9]}$. However, the strength of the cured ceramic green body made from aqueous suspension are much lower than that made from resin-based suspension. On the other hand, for some oxide ceramic particles (such as zirconia, alumina and silica), the existence of many hydroxy groups on surface makes these particles hydrophilic, thus accounts for the difficulty to disperse them efficiently in nonpolar UV-curable resins ${ }^{[10]}$. Previous researches concerning the impact on the dispersion and rheological behavior of slurries focused on these aspects including the dispersant choice and its optimum addition ${ }^{[10-11]}$, different solid contents and temperature $^{[12]}$, the composition and properties of monomers $^{[13]}$, and so on. The research of intrinsic relationship between powder characteristics and dispersion behavior of ceramic/resin suspension is relatively rare, although the ceramic powder is the major part of suspension.

The present study focuses on the rheological characterization of zirconia dispersions in mildly polar commercially available UV curable resin. The effects of powder

\footnotetext{
Received date: 2019-03-01; Revised date: 2019-04-15

Foundation item: National Key Research and Development Program of China (2017YFB0310400); National Natural Science Foundation of China (51572277, 51702340); Shanghai Sailing Program (17YF1428800); Natural Science Foundation of Shanghai (17ZR1434800)
}

Biography: LI Xing-Bang (1994-), male, Master candidate. E-mail: 455104949@qq.com 李兴邦(1994-), 男, 硕士研究生. E-mail: 455104949@qq.com

Corresponding author: ZHANG Jing-Xian, professor. E-mail: jxzhang@mail.sic.ac.cn 张景贤, 研究员. E-mail: jxzhang@mail.sic.ac.cn 
characteristics, such as specific surface area, particle size and distribution, morphology as well as solid loading on the slurry rheological behavior were investigated.

\section{Experimental procedure}

\subsection{Materials and slurry preparation}

A series of $3 \mathrm{~mol} \%$ yttria-stabilized zirconia (3YSZ) powders used in this work are shown in Table 1 with the information of their respective product name and supplier. All powders were used as received without any purification. A commercially available photocurable resin (SprintRay Inc., USA) was chosen as the organic binder to connect ceramic particles. The resin used in this work is a mixture of one or more acrylate-based oligomers and monomers, and a photoinitiator which can form radicals to initiate the photopolymerization reaction of acrylates under certain radiation with wavelength ranging from $355 \mathrm{~nm}$ to $405 \mathrm{~nm}$. Other details about the formulation of the resin has not been revealed by manufacturer to the public yet. VARIQUAT ${ }^{\circledR}$ CC 42 NS (Evonik, Germany) was used to disperse zirconia particles in all non-aqueous slurries with the concentration of $3 \mathrm{wt} \%$ relative to the powder weight. This dispersant is a polypropoxy quaternary ammonium chloride from the manufacturer's specifications.

The ceramic-resin suspensions were prepared by roll milling at a low speed of $60 \mathrm{r} / \mathrm{min}$. The low-speed does not change the particle size and distribution distinctly, as shown in Table 2 with No. 9 powder as the example. Firstly, the moderate amounts of YTZ ${ }^{\circledR}$ milling media (Nikkato Corp., Osaka, Japan) with a diameter of $5 \mathrm{~mm}$ were added into polyethylene bottles. The photosensitive resin was then added with the dispersant. The mixture

Table 1 Basic information of the raw powders used in this work

\begin{tabular}{|c|c|c|}
\hline No. & Product name & Supplier \\
\hline 1 & SZ-DT-SE2 & Jiangxi Size Materials Co., Ltd. \\
\hline 2 & YH-3YSZ & Yixingshi Yihui Naimo Cailiao Co., Ltd. \\
\hline 3 & $\mathrm{SG}-3 \mathrm{YB}-\mathrm{S}_{2} \mathrm{Z}_{0}-\mathrm{E}$ & $\begin{array}{l}\text { Dongguan CSG Ceramics Technology } \\
\text { Co., Ltd. }\end{array}$ \\
\hline 4 & OZ-3Y-6 & $\begin{array}{l}\text { Guangdong Orient Zirconic Ind Sci \& } \\
\text { Tech Co., Ltd. }\end{array}$ \\
\hline 5 & TYSZ-3-S & Hubei Jing Gui Zirconium Co., Ltd. \\
\hline 6 & HWYA-N-3S & $\begin{array}{l}\text { GuangDong Huawang Zirconium } \\
\text { Materials Co., Ltd. }\end{array}$ \\
\hline 7 & G3Y-020OO & $\begin{array}{l}\text { Shandong Sinocera Functional Material } \\
\text { Co., Ltd. }\end{array}$ \\
\hline 8 & SZ-DM-3.0-F3 & Jiangxi Size Materials Co., Ltd. \\
\hline 9 & TZ-3YSE & Tosoh Corp., Tokyo, Japan \\
\hline
\end{tabular}

Table 2 Particle size and distribution of No. 9 powder before and after ball milling

\begin{tabular}{cccc}
\hline Powder & $d_{10} / \mathrm{nm}$ & $d_{50} / \mathrm{nm}$ & $d_{90} / \mathrm{nm}$ \\
\hline Before roll milling & 196.7 & 316.9 & 510.3 \\
After roll milling & 207.0 & 318.0 & 488.4 \\
\hline
\end{tabular}

was subsequently roll milled for about $30 \mathrm{~min}$ to dissolve the dispersant. Zirconia powders were added and the suspensions were blended for at least one day by roll milling.

\subsection{Characterization}

The specific surface areas and particle size distributions of powders were measured in the absence of dispersant, using ASAP2010 (Micromeritics, USA) and BI-XDC (Brookhaven, USA) respectively. Rheological measurements of the freshly prepared zirconia slurries were conducted on a plate-plate rotational rheometer MCR 301 (Anton Paar, Austria) at $25{ }^{\circ} \mathrm{C}$. The parallel plate diameter used was $25 \mathrm{~mm}$, and the gap between the plates was $1 \mathrm{~mm}$. The experiments carried out by ascending and descending shear rate ranged from $10^{-3} \mathrm{~s}^{-1}$ to $10^{3} \mathrm{~s}^{-1}$ and from $10^{3} \mathrm{~s}^{-1}$ to $10^{-3} \mathrm{~s}^{-1}$, with 10 points of data collected at each order of magnitude and duration of $2 \mathrm{~s}$ for each testing point. The morphologies of the powders were observed by using scanning electron microscopy (S-4800, Hitachi, Japan).

\section{Results and discussion}

Fig. 1 shows the rheological curves of $35 \mathrm{vol} \%$ slurries with the same dispersant (VARIQUAT ${ }^{\circledR}$ CC $42 \mathrm{NS}$, $3 \mathrm{wt} \%$ on a dry weight basis of ceramic powders), using different powders as the filler respectively. It can be seen that the suspensions show great difference in terms of rheological behavior, which can be attributed to different powders' characteristics. The particle size distributions and BET specific surface areas of the raw powders are shown in Table 3 , in order of viscosity value measured at

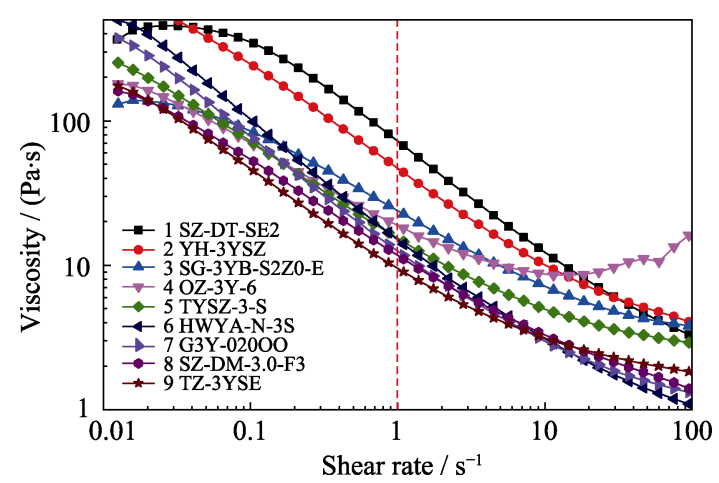

Fig. 1 Viscosity as a function of shear rate for $35 \mathrm{vol} \%$ dispersions with different powders 
Table 3 Particle size distribution and BET specific surface area of raw powders

\begin{tabular}{cccccc}
\hline No. & $d_{10} / \mathrm{nm}$ & $d_{50} / \mathrm{nm}$ & $d_{90} / \mathrm{nm}$ & $\begin{array}{c}S_{\mathrm{BET}} / \\
\left(\mathrm{m}^{2} \cdot \mathrm{g}^{-1}\right)\end{array}$ & $\begin{array}{c}\text { Slurry viscosity/ } \\
(\mathrm{Pa} \cdot \mathrm{s})\end{array}$ \\
\hline 1 & 172.7 & 283.3 & 464.6 & 15.596 & 67.2 \\
2 & 323.2 & 577.6 & 1032.3 & 8.643 & 43.8 \\
3 & 146.0 & 252.4 & 436.5 & 15.712 & 22.6 \\
4 & 180.3 & 309.1 & 529.9 & 17.521 & 18 \\
5 & 229.0 & 390.3 & 665.3 & 8.194 & 14.5 \\
6 & 140.1 & 206.6 & 304.5 & 9.236 & 14 \\
7 & 236.5 & 386.4 & 631.4 & 9.18 & 11.7 \\
8 & 169.2 & 300.0 & 531.7 & 10.188 & 11 \\
9 & 196.7 & 316.9 & 510.3 & 7.133 & 9 \\
\hline
\end{tabular}

a low shear rate of $1 \mathrm{~s}^{-1}$ corresponding to the dotted line in Fig. 1. The viscosities of slurries prepared from powders with high specific surface area such as No. 1, 3 and 4 are much higher than those with low BET surface area like No. 7, 8 and 9. To the best of the authors' knowledge, it is difficult to obtain highly concentrated dispersions using powders with high specific surface area. Because this kind of powder need more liquid phase to wet the surface compared with others in the same case, which can cause the relative decrease of free liquid phase amount in suspension and therefore increases the frictional resistance resulting from relative motion between particles. In addition, serious particle agglomeration takes place more easily in the process of slurry preparation using powder with high specific surface area because of its higher surface energy.

As can be seen in Table 3, No. 4, 8 and 9 powders have similar particle size distributions but different BET specific surface areas, and No. 5, 6 and 7 powders are the exact opposite. Fig. 2(a) shows the viscosites of slurry 4 , 8 and 9 as function of shear rate. Slurry 4 shows higher viscosity value in the full shear rates range due to its high specific surface area $\left(17.521 \mathrm{~m}^{2} / \mathrm{g}\right)$ compared with slurry 8 and 9 , and exhibits shear-thickening behavior above the shear rate of $10 \mathrm{~s}^{-1}$. This phenomenon can be explained by the destruction of slurry original microstructure when the shear rate exceeds a certain value. Shear-thickening behavior should be avoided because it is difficult for the scraper to spread the slurry evenly. As shown in Table 3, the specific surface area of powder $6\left(9.236 \mathrm{~m}^{2} / \mathrm{g}\right)$ is quite close to that of powder $7\left(9.18 \mathrm{~m}^{2} / \mathrm{g}\right)$, which can account for the considerable overlap between the rheological curves (Fig. 2(b)). The viscosity of slurry 5 is slightly higher than that of slurry 7 after $1 \mathrm{~s}^{-1}$ in spite of their close specific surface areas, which may derive from the morphological differences of two powders. It can be seen in Fig. 3 that powder 7 has the regular near-spherical shape whereas the morphology of powder 5 is more angular. The spherical shapes of powder 7 and 9 decrease the frictional resistance among particles and thus increase the chances of achieving a high solid loading ${ }^{[14-15]}$.

On the basis of the above analysis, No. 9 powder was chosen as the ceramic filler in the following study. Highly
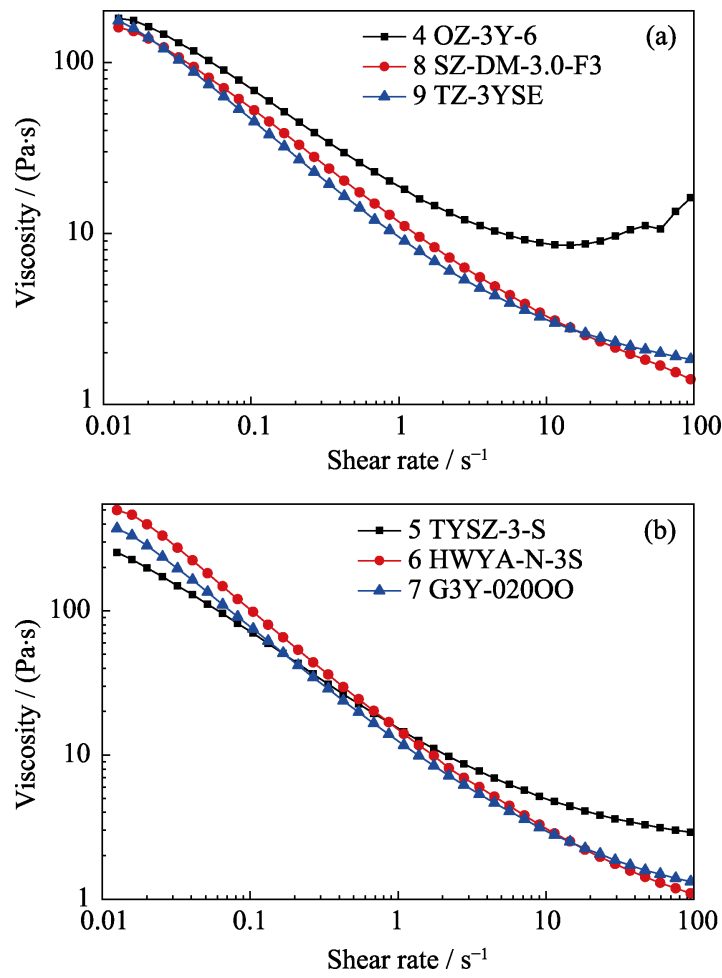

Fig. 2 Rheological curves of slurries using powders with (a) similar particle size distribution and (b) similar specific surface area
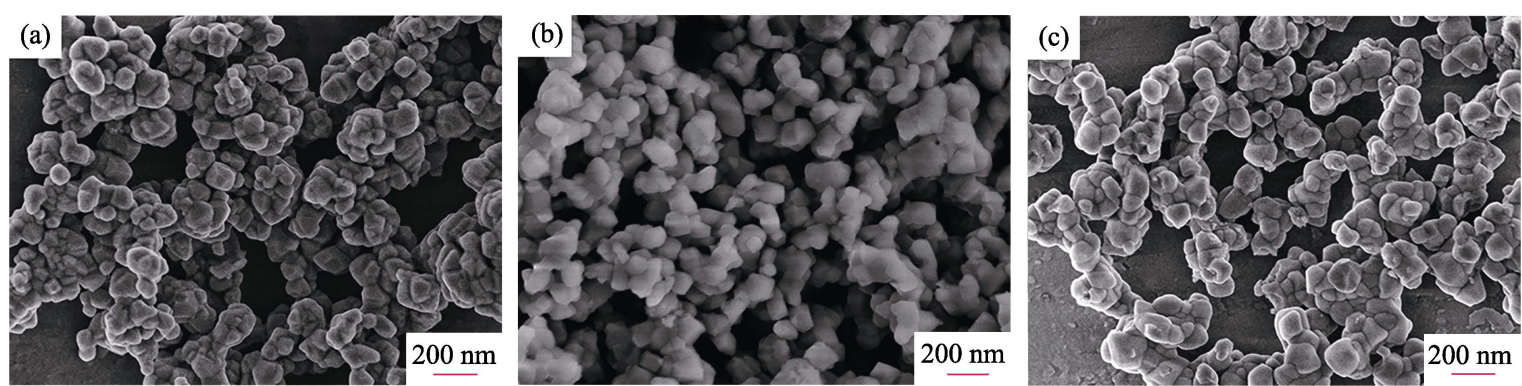

Fig. 3 SEM images of (a) No. 7 powder, (b) No. 5 powder and (c) No. 9 powder 
concentrated slurry is in favor of achieving the densification of sintering body, thus it is necessary to study the influence of solid loading on rheological behavior. Fig. 4 shows the rheological curves of slurries with solid loading varying from $35 \mathrm{vol} \%$ to $44 \mathrm{vol} \%$. It can be observed that the higher the solid loading, the higher the slurry viscosity is. The $35 \mathrm{vol} \%$ and $40 \mathrm{vol} \%$ suspensions exhibited significant shear-thinning behavior over the whole shear rate ranging from $0.01 \mathrm{~s}^{-1}$ to $200 \mathrm{~s}^{-1}$, whereas the flow behavior of $42 \mathrm{vol} \%$ and $44 \mathrm{vol} \%$ suspensions change to dilatancy for shear rates higher than approx. 60 and $30 \mathrm{~s}^{-1}$ respectively. High solid content results in small interparticle spacing, which may increase flow resistance greatly.

Figure 5 shows the relative viscosity at $30 \mathrm{~s}^{-1}$ as a function of ceramic volume fraction, for the suspensions with the same dispersant (VARIQUAT ${ }^{\circledR}$ CC 42 NS, $3 \mathrm{wt} \%$ on a dry weight basis of ceramic powders). The relative viscosity increases slowly as the zirconia loading increases from 0 to $40 \mathrm{vol} \%$, however it undergoes a sharp rise above $40 \mathrm{vol} \%$. The Krieger-Dougherty model ${ }^{[16]}$ can be used to give a good estimation of this relationship:

$$
\eta_{r}=\frac{\eta}{\eta_{0}}=\left(1-\frac{\Phi}{\Phi_{\mathrm{m}}}\right)^{-[\eta] \Phi_{\mathrm{m}}}
$$

where $\eta_{\mathrm{r}}$ is the relative viscosity, $\eta$ is the viscosity of the

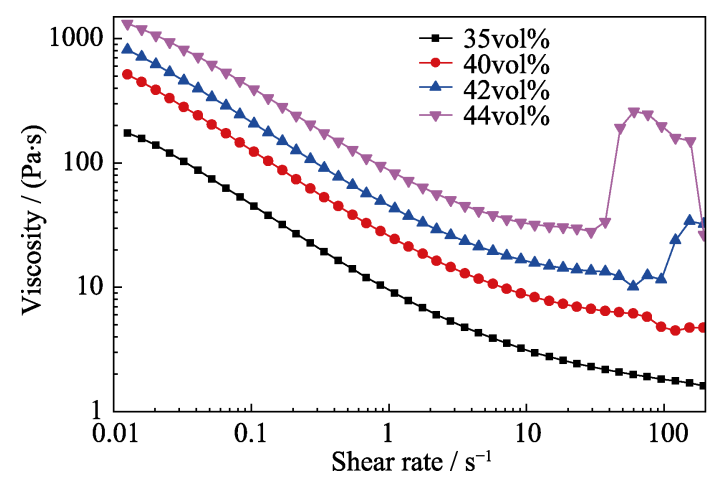

Fig. 4 Rheological behavior of slurries with different solid loadings

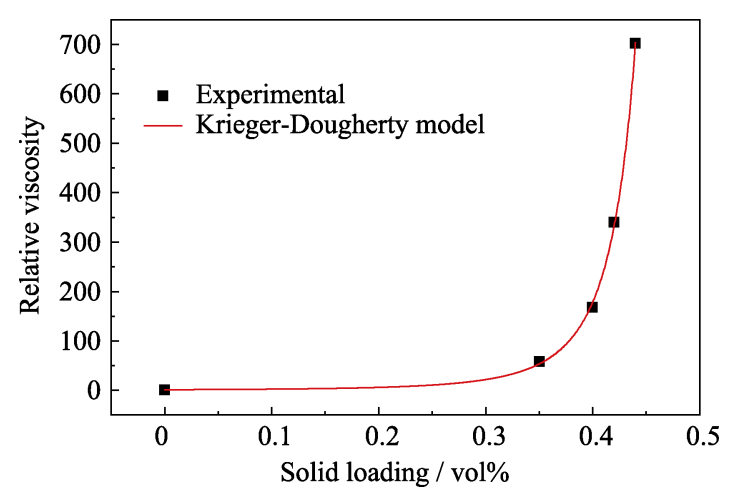

Fig. 5 Relative viscosity of slurries as a function of solid loading at the shear rate of $30 \mathrm{~s}^{-1}$
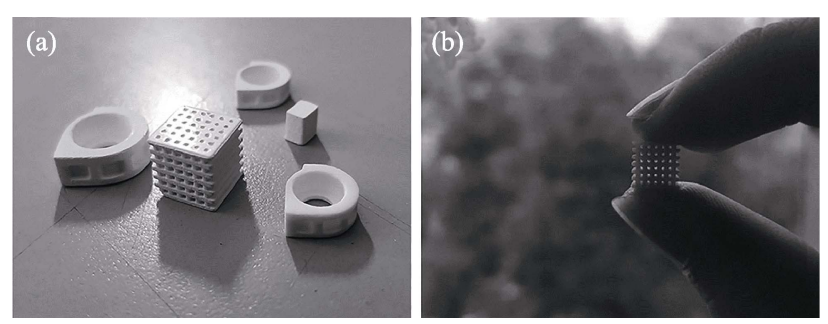

Fig. 6 Optical pictures of green (a) and sintered (b) zirconia parts fabricated by stereolithography

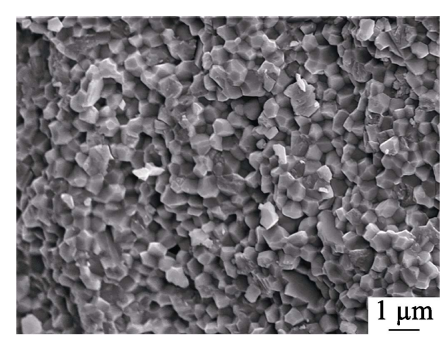

Fig. 7 SEM image of the fracture surface of the sintered part

suspension, $\eta_{0}$ is the viscosity of the medium, $\Phi$ is the volume fraction of the ceramic powder, $\Phi_{\mathrm{m}}$ is the maximum volume fraction of particles in slurry, and $[\eta]$ is the intrinsic viscosity of the suspension. In this work, the fitting parameter $\Phi_{\mathrm{m}}$ is 0.528 and the $R$-square value is 0.9994.

Fig. 6 shows the optical pictures of complex-shaped zirconia green and sintered parts, derived from the suspension with a solid loading of $40 \mathrm{vol} \%$. These parts were printed by a DLP-based stereolithography apparatus (ADMAFLEX 130, ADMATEC Europe BV, The Netherlands) and heat-treated at $1550{ }^{\circ} \mathrm{C}$ with holding time of $1 \mathrm{~h}$. Finally, zirconia samples with the relative density of $(97.83 \pm 0.33) \%$ were obtained after sintering at $1550{ }^{\circ} \mathrm{C}$. The sintering shrinkage in length, width and height were $(23.15 \pm 0.13) \%$, $(23.47 \pm 0.02) \%$ and $(23.80 \pm 0.09) \%$ respectively. No obvious abnormal grain growth in the microstructure of the sintered body was observed in Fig. 7. Results indicated that after the optimization of the processing parameters with the help of rheology characterization, complex-shaped high-quality zirconia parts can be obtained using the stereolithography technique.

\section{Conclusions}

In this work, the rheological behavior of photocurable zirconia resin-based slurries prepared from different powders was studied. Results showed that the powders' characteristics have a noticeable effect on the slurry rheology, and the specific surface area of the powder is the major factor. The suspension containing the selected TZ-3YSE powder exhibits the lowest viscosity at shear rates ranging from $0.1 \mathrm{~s}^{-1}$ to $10 \mathrm{~s}^{-1}$, owing to its low spe- 
cific surface area and spherical morphology. The KriegerDougherty model can be used to explain the relationship between solid loading and slurry viscosity. Results shown in this study are applicable for preparing high solid loading, low viscosity zirconia or other structural ceramic photosensitive slurries used for stereolithography applications.

\section{References:}

[1] CHEN WEI-CEN, WANG FANG-FANG, YAN KANG, et al. Microstereolithography of KNN-based lead-free piezoceramics. Ceramics International, 2019, 45(4): 4880-4885.

[2] CHEN YAN, BAO XIU-LAN, WONG CHI-MAN, et al. PZT ceramics fabricated based on stereolithography for an ultrasound transducer array application. Ceramics International, 2018, 44(18): 22725-22730.

[3] ZHOU MAO-PENG, LIU WEI, WU HAI-DONG, et al. Preparation of a defect-free alumina cutting tool via additive manufacturing based on stereolithography-optimization of the drying and debinding processes. Ceramics International, 2016, 42(10): 11598-11602.

[4] BAE CHANG-JUN, KIM DANIEL, HALLORAN JOHN W. Mechanical and kinetic studies on the refractory fused silica of integrally cored ceramic mold fabricated by additive manufacturing. Journal of the European Ceramic Society, 2019, 39(2): 618-623.

[5] MASCIANDARO S, TORRELL M, LEONE P, et al. Threedimensional printed yttria-stabilized zirconia self-supported electrolytes for solid oxide fuel cell applications. Journal of the European Ceramic Society, 2019, 39(1): 9-16.

[6] WEI LU-YANG, ZHANG JIN-JIN, YU FANG-YONG, et al. A novel fabrication of yttria-stabilized-zirconia dense electrolyte for solid oxide fuel cells by 3D printing technique. International Journal of Hydrogen Energy, 2019, 44(12): 6182-6191.

[7] ZHOU WEI-ZHAO, LI DI-CHEN, WANG HUI. A novel aqueous ceramic suspension for ceramic stereolithography. Rapid Proto- typing Journal, 2010, 16(1): 29-35.

[8] WU HAI-DONG, CHENG YAN-LING, LIU WEI, et al. Effect of the particle size and the debinding process on the density of alumina ceramics fabricated by 3D printing based on stereolithography. Ceramics International, 2016, 42(15): 17290-17294.

[9] WU HAI-DONG, LIU WEI, HE RONG-XUAN, et al. Fabrication of dense zirconia-toughened alumina ceramics through a stereolithography-based additive manufacturing. Ceramics International, 2017, 43(1): 968-972.

[10] ZHANG SHUAI, SHA NA, ZHAO ZHE. Surface modification of $\alpha-\mathrm{Al}_{2} \mathrm{O}_{3}$ with dicarboxylic acids for the preparation of UV-curable ceramic suspensions. Journal of the European Ceramic Society, 2017, 37(4): 1607-1616.

[11] SONG SE-YEON, PARK MIN-SOO, LEE JUNG-WOO, et al. A study on the rheological and mechanical properties of photo-curable ceramic/polymer composites with different silane coupling agents for SLA 3D printing technology. Nanomaterials, 2018, 8(2): 93-104.

[12] WOZNIAK MACIEJ, DE HAZAN YORAM, GRAULE THOMAS, et al. Rheology of UV curable colloidal silica dispersions for rapid prototyping applications. Journal of the European Ceramic Society, 2011, 31(13): 2221-2229.

[13] ADAKE CHANDRASHEKHAR V, BHARGAVA PARAG, GANDHI PRASANNA. Effect of surfactant on dispersion of alumina in photopolymerizable monomers and their UV curing behavior for microstereolithography. Ceramics International, 2015, 41(4): 5301-5308.

[14] ZHANG KE-QIANG, XIE CHEN, WANG GANG, et al. High solid loading, low viscosity photosensitive $\mathrm{Al}_{2} \mathrm{O}_{3}$ slurry for stereolithography based additive manufacturing. Ceramics International, 2019, 45(1): 203-208.

[15] WU XIANG-QUAN, LIAN QIN, LI DI-CHEN, et al. Influence of boundary masks on dimensions and surface roughness using segmented exposure in ceramic 3D printing. Ceramics International, 2019, 45(3): 3687-3697.

[16] KRIEGER IRVIN M, DOUGHERTY THOMAS J. A mechanism for non-newtonian flow in suspensions of rigid spheres. Transactions of the Society of Rheology, 1959, 3(1): 137-152.

\section{粉体性质对树脂基氧化锆光固化浆料流变行为的影响}

$$
\text { 李兴邦 }{ }^{1,2} \text {, 仲 } \text { 鹤 }^{1} \text {, 张景贤 }{ }^{1,3} \text {, 段于森 }{ }^{1,2} \text {, 江东亮 }{ }^{1}
$$

(1. 中国科学院 上海硅酸盐研究所, 高性能陶瓷和超微结构国家重点实验室, 上海 200050; 2. 中国科学院大学, 北京 100049; 3. 中国科学院 上海硅酸盐研究所, 苏州研究院, 太仓 215499)

摘 要: 合适的树脂基陶瓷浆料的制备对陶瓷光固化成型技术而言至关重要。本文研究了氧化锆粉体的性质，包括 比表面积、粒度与粒径分布、颗粒形貌等因素对树脂基浆料流变行为的影响。研究发现: 粉体的比表面积是影响浆 料粘度的最主要因素。选择低比表面积、形貌接近球形的粉体更容易制备出低粘度的浆料。利用 Krieger-Dougherty 模型研究了粉体固含量对浆料流变行为的影响。在 $1550{ }^{\circ} \mathrm{C}$ 烧结得到了相对密度为 $(97.83 \pm 0.33) \%$ 的氧化锆陶瓷, 未 发现明显的晶粒异常长大, 表明基于流变学表征方法对浆料制备参数进行优化后, 采用光固化技术可以制备出复 杂结构、高质量的氧化锆陶瓷。

关 键 词: 氧化铅; 陶瓷光固化成型; 浆料; 流变性质

中图分类号: TQ174 文献标识码: A 